\title{
Kegiatan Marketing Pr Label Musik Digital Audio Tape Bandung
}

\section{Fadil Ramadhan*, M. Subur Drajat}

Prodi Ilmu Hubungan Masyarakat, Fakultas Ilmu Komunikasi, Universitas Islam Bandung, Indonesia.

*mfadilramadhan126@gmail.com, m.suburdrajat@gmail.com

\begin{abstract}
Music labels Digital Audio Tape having the marketing public relations that his services can be used by audience. The marketing public relations label was set up by Trizha Harun as public relations at the music labels Digital Audio Tape. ( ruslan 2008: 249), Public relations serves to communicate both sides between the company with public internal and external relationships and mutual with the audience be considered important by label. Activity public relations is held mutual communication between institution with public intended to create mutual understanding and support for the achievement of a a particular purpose, policy, production activities the progress of institution or a positive image of institutions concerned. The public function of relations at the labels music Digital Audio Tape to increase the consumers which will perform recording on music label Digital Audio Tape. The purpose of this research that is to know the marketing public relations done by music labels Digital Audio Tape. The methodology qualitative perspective case study by Robert K. Yin more trying to map technique single case analysis in the analysis the marketing public relations done by music labels Digital Audio Tape. The research music label the concept of representatives using three with the creation event showcase cover tune in instagram, created an impromptu event or shocking venues, combining vocal technique of various genre of music becomes hip hop.
\end{abstract}

Keywords: Marketing Public Relations, Label music, Digital Audio Tape Bandung.

Abstrak. Label music Digital Audio Tape memiliki kegiatan marketing Public Relations agar jasanya dapat digunakan oleh khalayak. Kegiatan marketing Public Relations label tersebut dibuat oleh Trizha Harun selaku Public Relations pada label musik Digital Audio Tape. (Ruslan 2008 :249), Public Relations berfungsi untuk menjalin komunikasi dua arah antara perusahaan dengan publik internal dan eksternal serta membina hubungan yang saling menguntungkan dengan khalayak atau pihak yang dianggap penting oleh label. Aktivitas Public Relations adalah menyelenggarakan komunikasi timbal balik antara lembaga dengan publik yang bertujuan untuk menciptakan saling pengertian dan dukungan bagi tercapainya suatu tujuan tertentu, kebijakan, kegiatan produksi demi kemajuan lembaga atau citra positif lembaga bersangkutan. Fungsi Public Relations pada label musik Digital Audio Tape untuk meningkatkan pelaku konsumen yang akan melakukan rekaman di label musik Digital Audio Tape. Tujuan penelitian ini yaitu untuk mengetahui kegiatan marketing public relations yang dilakukan oleh label musik Digital Audio Tape. Metode penelitian kualitatif dengan perspektif studi kasus Robert K. Yin yang lebih berupaya memetakan teknik single case analysis pada analisis kegiatan marketing public relations yang dilakukan oleh label musik Digital Audio Tape. Dari hasil penelitian label musik menggunakan tiga konsep MPR dengan cara menciptakan event showcase cover lagu di instagram, menciptakan mengadakan event dadakan atau (shocking venue), menggabungkan teknik vocal dari berbagai genre musik menjadi hip hop.

Kata Kunci: Marketing Public Relations, Label Musik, Digital Auto Tape Bandung 


\section{A. Pendahuluan}

Aktivitas Public Relations adalah menyelenggarakan komunikasi timbal balik antara lembaga dengan publik yang bertujuan untuk menciptakan saling pengertian dan dukungan bagi tercapainya suatu tujuan tertentu, kebijakan, kegiatan produksi demi kemajuan lembaga atau citra positif lembaga bersangkutan. Fungsi Public Relations pada label musik Digital Audio Tape untuk meningkatkan pelaku konsumen yang akan melakukan rekaman di label musik Digital Audio Tape.

Seorang Public Relations harus mempunyai kegiatan untuk mencapai tujuan perusahaan, salah satunya menarik minat pelanggan agar terus menggunakan jasanya.

Kegiatan marketing public relations sebagai suatu proses perencanaan, pelaksanaan, dan pengevaluasian program-program yang memungkinkan terjadinya daya tarik musisi atau masyarakat terhadap penggunaan jasa atau produk dari label musik Digital Audio Tape yang disesuaikan dengan kebutuhan, keinginan, perhatian dan kesan dari para musisi atau masyarakat sebagai konsumennya. (Ruslan 2008 :249), Marketing Public Relations merupakan perpaduan (sinergi) antara pelaksanaan program dan kegiatan pemasaran (marketing strategy implementation) dengan aktivitas program kerja humas (work program of $P R$ ) dalam upaya meluaskan pemasaran dan demi mencapai kepuasan konsumennya,

Persaingan bisnis dalam bidang industri label musik membuat label Digital Audio Tape harus menciptakan kegiatan marketing Public Relations terbaik. Keadaan ini merupakan salah satu tantangan yang harus dihadapi Label musik Digital Audio Tape untuk memenangkan persaingan, semakin tinggi tingkat persaingan antara perusahaan label musik menyebabkan penyedia jasa rekaman musik akan meningkatkan pelayanan serta fasilitas untuk para musisi.

Dari uraian masalah di atas, peneliti mencoba merumuskan masalah yang akan diteliti sebagai berikut: "Bagaimana kegiatan marketing public relations yang dilakukan oleh label musik Digital Audio Tape?". Untuk memperjelas masalah yang akan dibahas dalam penelitian ini, maka identifikasi masalah yang akan diteliti adalah sebagai berikut :

1. Bagaimana marketing public Relations yang dilakukan oleh label musik Digital Audio Tape?

2. Bagaimana menangani hambatan yang terjadi pada promosi yang dilakukan oleh label musik Digital Audio Tape?

3. Mengapa Digital Audio Tape melakukan promosi melalui group rapper Green Flame?

\section{B. Landasan Teori}

\section{Komunikasi}

Komunikasi adalah suatu proses di mana dua orang atau lebih membentuk atau melakukan pertukaran informasi dengan satu sama lainnya, yang pada gilirannnya akan tiba pada saling pengertian yang mendalam (Cangara, 2005:19). Komunikasi pada akhirnya tidak hanya membantu atau menciptakan image/citra positif pada label Digital Audio Tape namun juga membangun kepercayaan terhadap publik sehingga mereka percaya dengan apa yg dilakukan label Digital Audio Tape adalah yg terbaik dan mengharumkan namanya

\section{Public Relations}

Public Relations adalah fungsi manajemen yang menilai sikap-sikap publik, mengidentifikasi kebijakan-kebijakan dan prosedur-prosedur dari individu atau organisasi atas dasar kepentingan publik dan melaksanakan rencana kerja untuk memperoleh pengertian dan pengakuan publik (Ardianto, 2011: 8). Aktivitas Public Relations sehari-hari adalah menyelenggarakan komunikasi timbal balik (two-way traffic) antara pihak Label Digital Audio Tape dan pihak konsumen yang bertujuan untuk menciptakan saling pengertian dan dukungan bagi tercapainya suatu tujuan tertentu, kebijakan, kegiatan-kegiatan demi kemajuan lembaga atau citra positif lembaga bersangkutan.

\section{Marketing Public Relations}

Marketing Public Relations adalah sebuah proses perencanaan dan pengevaluaisan program yang merangsang penjualan dan pelanggan. Hal tersebut dilakukan melalui pengkomunikasian 
informasi yang kredibel dan kesan-kesan yang dapat menghubungkan perusahaan, produk dengan kebutuhan derta perhatian pelanggan (Alifahmi, 2008: 245).

Terdapat pada 3 taktik MPR yaitu Three Ways Marketing untuk melaksanakan program dalam mencapai tujuan. Dalam buku Rosady Ruslan di jelaskan 3 taktik tersebut yaitu:

1. Push Strategy (Mendorong), merupakan upaya untuk merangsang (mendorong) pembelian sekaligus, dapat memberikan nila-nilai (added value) atau kepuasan bagi pelanggan (satisfied costumer) yang telah menggunakan produk perusahaan. Penggunaan Push Strategy (mendorong) yang diciptakan oleh executive public relation Digital Audio Tape berupa selalu mengupayakan agar masyarakat yang menjadi talent dan calon talent potensi dapat memberikan nilai-nilai (added atau kepuasan bagi masyarakat (satisfied costumer) yang berminat rekaman di label musik Digital Audio Tape.

2. Pull Strategy (Menarik), Public Relations merupakan potensi untuk menyandang suatu taktik menarik perhatian dengan berbagai cara guna mencapainya tujuan perusahaan serta meningkatkan penjualan baik berupa jasa atau barang. Pull strategy yang diciptakan oleh executive public relation Digital Audio Tape mempromosikan secara besar-besaran melalui event showcase cover lagu di instagram yang di mana dalam mencari talent potensi pihak label selalu mempromosikan kegiatan cover lagu di instagram yang di mana bagi siapa saja dari masyarakat pengguna instagram yang tertarik untuk mengikuti dan mengcover lagu di persilahkan dengan syarat tertentu.

3. Pass Strategy (Membujuk), sebagai upaya untuk menciptakan image publik yang ditimbulkan melalui berbagai kegiatan, dan berpatisipasi dalam kegiatan kemasyarakatan atau tanggung jawab sosial, serta kepedulian terhadap masalah-masalah yang berkaitan dengan kondisi sosial, (Alifahmi, 2008: 246). Penggunaan Pass Strategy (membujuk), yang diciptakan oleh executive public relation Digital Audio Tape berupa selalu menciptakan event - event sosial seperti charity gempa Donggala, Penggusuran Taman Sari, charity untuk korban banjir, dan charity lain yang menyangkut tentang kemanusiaan. Biasanya label dan para talent khususnya grup Green Flame selalu mengadakan event kemanusiaan tersebut dengan dana sumbangan event yang terkumpul biasanya langsung di serahkan kepada korban dengan bukti dokumentasi bahwa label dan talent pernah melakukan event charity untuk kemanusiaan.

\section{Hasil Penelitian dan Pembahasan}

Untuk lebih menjelaskan secara keseluruhan hasil dari penelitian ini, penulis akan menjelaskan dengan menggunakan skema gambar mengenai hasil temuan penelitian sebagai berikut:

Pertanyaan penelitian yang pertama berupa "Bagaimana marketing public Relations yang dilakukan oleh label musik Digital Audio Tape". Temuan penelitian di lapangan dari hasil wawancara dengan dua narasumber dapat di representasikan bahwa strategi promosi melalui word of mouth tidak berhasil. Pihak label menciptakan salah satu kegiatan MPR diantaranya: Menciptakan dan mengadakan event showcase cover lagu di instagram untuk mencari bakat talent yang telah di tentukan label. Setiap individu yang punya potensi biasanya di gabungkan dengan talent lain dari berbagai macam genre menjadi jenis musik hip-hop dengan vocal yang beragam.

Adapun hasil pembahasan penelitiannya bahwa dalam melakukan promosi untuk menarik perhatian konsumen agar menggunakan jasa studio rekaman, serta dikelola manajemen artisnya oleh pihak label Digital Audio Tape. Pihak label menggunakan three-way strategy yaitu: pull, push, pass strategy di mana ketiga konsep tersebut satu sama lainnya saling berkaitan dan berhubungan. Menurut peernyataan dan pandangan dari ketiga narasumber di ciptakannya three way strategy pada kegiatan marketing public Relations yang dilakukan oleh label musik Digital Audio Tape bertujuan untuk menciptakan daya tarik, mendorong, serta membujuk masyarakat sebagai calon talent potensi agar lebih kenal lebih jauh tentang label sehingga mempunyai peminatan terhadap label sehingga terdorong untuk menggunakan jasa rekaman di label serta berminat untuk di manajemen keartisannya. 
Untuk pertanyaan kedua berupa "Bagaimana menangani hambatan yang terjadi pada promosi yang dilakukan oleh label musik Digital Audio Tape". Pihak executive public relation Digital Audio Tape menciptakan solusi berupa membangun komunikasi yang baik secara berkala dengan para talent potensi. Di sini pihak label terus membentuk komunikasi yang dapat menciptakan daya minat talent potensi untuk bekerjasama dan rilisan lagunya di label. Selain itu, pihak label burusaha peduli atas kondisi yang dialami oleh para talent potensinya, dengan cara bertanya tentang keadaan. Memberi kabar terlebih dahulu dengan menggunakan bahasa pesan yang baik, sopan, mudah di mengerti tanpa harus mengawali dengan bisnis kerjasama.

Berdasarkan hasil temuan penelitian dapat di representasikan untuk mengatasi hambatan yang terjadi pada promosi yang dilakukan oleh label musik Digital Audio Tape, pihak executive public relation Digital Audio Tape berusaha menciptakan dan membangun komunikasi yang baik dengan para kompetitor dan stockholder dengan cara membangun ikatan emosioal antara label dan kompetitor ataupun stockholder. Tujuannya untuk menciptakan beberapa aspek terutama adanya bantuan dari pihak kompetitor atapun stokeholder untuk memperkenalkan label dengan di bangunkan karater label sesuai dengan talent yang cocok. Aspek lain berupa biasanya kompetitor atapun stokeholder yang sudah di bangun komunikasinya akan membantu dalam segi penjualan sesuai dengan karakter studionya.

Berdasarkan hasil temuan penelitian untuk mengatasi hambatan pada komunikasi antar fans dengan talent group rapper Green Flame, pihak executive public relation Digital Audio Tape berusaha menciptakan dan membangun komunikasi yang baik antara fans dengan talentnya yaitu group rapper Green Flame memelihara fans dengan talent dengan cara setiap satu minggu para fans bisa bersilaturahmi dengan kunjungan ke official group rapper Green Flame di mana kedua belah pihak bisa berkomunikasi dan berbagi informasi seputar musik, event, dan lain sebagainya yang dapat menjaga komunikasi diantara fans dan talent-nya.

Hasil pembahasannya berupa untuk mengatasi atau menangani hambatan yang terjadi pada promosi yang dilakukan oleh label musik Digital Audio Tape, executive public relation Digital Audio Tape berusaha membangun komunikasi baik dengan talent potensi agar bermitra, ataupun bekerjasama dengan label dan merilis single atau albumnya di label Digital Audio Tape serta membangun branding label bersama-sama. Selain itu, executive public relation Digital Audio Tape berusaha membangun komunikasi dengan Kompetitor dan stokeholder dengan tujuan untuk menciptakan beberapa aspek terutama adanya bantuan dari pihak kompetitor atapun stokeholder untuk memperkenalkan label dengan di bangunkan karater label sesuai dengan talent yang cocok. Aspek lain berupa biasanya kompetitor atapun stokeholder yang sudah di bangun komunikasinya akan membantu dalam segi penjualan sesuai dengan karakter studionya.

Serta pihak executive public relation Digital Audio Tape berusaha membangun komunikasi yang baik diantara fans dengan talent group rapper Green Flame. Hal tersebut bertujuan untuk membangun ikatan emosional di antara fans dengan artisnya yaitu group rapper Green Flame yang di mana kedua belah pihak akan terus berkordinasi, berkomunikasi dengan akrab karena pihak label akan memfasilitasi kegiatan bertemu idola dalam satu minggu sekali di mana para fans secara langsung akan bertemu group rapper Green Flame, ngobrol santai bersama, akan mengetahui jadwal event group rapper Green Flame, rilis single berikutnya dan lain sebagainya yang dapat mempermudah komunikasi tatap muka antara fans dengan group rapper Green Flame sebagai artis idolanya.

Sementara untuk pertanyaan ketiga yaitu "Mengapa Digital Audio Tape melakukan promosi melalui group rapper Green Flame" temuan penelitian lapangan label Digital Audio Tape mempromosikan dirinya dengan genre musik hip hop yang di munculkan group rapper Green Flame, karena pertama executive public relation Digital Audio Tape menganggap bahwa hal tersebut sebagai salah satu strategi dalam menciptakan pasar potensial, karena berdasarkan evaluasi ternyata musik yang lagi di sukai di zaman millennial ini yaitu hip-hop hal tersebut juga terlahir dari referensi video Rich Chigga dari Indonesia yang sempat besar dan viral secara internasional. Musik hip-hop bagi label adalah ladang market yang menjanjikan karena musik tersebut mulai banyak di sukai masyarakat sebagai khalayak pendengarnya. Oleh karena itu, pihak label memilih Green Flame karena setiap personal dari talent tersebut mempunyai karaker 
yang berbeda karena grup tersebut di bentuk dari berbagai genre musik yang di satukan menjadi genre hip hop yang unik, berbeda serta mencitakan daya tarik bagi masyarakat sebagai khalayak pendengarnya.

Alasan mempromosikan Green Flame yaitu untuk membentuk citra perushaan melalui statement atau opini publik pada saat melihat dan mendengarkan musik hip hop Green Flame yang di mana label menciptakan grup tersebut dengan konsep hip-hop berbeda penuh warna karena Green Flame di bentuk dari para talent yang mempunyai genre musik yang berbeda, di satukan menjadi jenis hip hop tanpa merubah karakter dari genre musik yang di bawakan oleh setiap personal talent-nya. Hal tersebutlah yang menjadi kemudian pihak label menjawab alasan dalam mempromosikan produk jasa labelnya yaitu Green Flame.

Proses memasarkan Green Flame itu sendiri rilisannya dimasukan di berbagai macam layanan musik streaming seperti JOOX Music, Sportify, Shazam, Musixmach. Songflip, Google play music, Amazon music, Deezer, Itunes, dan lain sebagainya. Sementara untuk kegiatan lainnya yaitu membangun kerjasama dengan resto and café, bar and resto serta event organizer agar grup Green Flame bisa tampil secara off air di berbagai tempat.

Hasil pembahasan berupa alasan Digital Audio Tape melakukan promosi melalui group rapper Green Flame pertama musik hip hop sebagai musik yang menjanjikan di era digital saat ini, di mana masyarakat sebagai khalayak sudah mulai mengenal dan menyukai musik tersebut. Sementara dalam mempromosikan dan memarketingkan grup Green Flame hal tersebut di sebabkan karena grup tersebut memunyai konsep hip-hop berbeda penuh warna karena Green Flame di bentuk dari para talent yang mempunyai genre musik yang berbeda, di satukan menjadi jenis hip hop tanpa merubah karakter dari genre musik yang di bawakan oleh setiap personal talent-nya. Hal tersebutlah yang menjadi kemudian pihak label menjawab alasan dalam mempromosikan produk jasa labelnya yaitu Green Flame.

Sementara dalam proses memasarkan Green Flame itu sendiri rilisannya dimasukan di berbagai macam layanan musik streaming seperti JOOX Music, Sportify, Shazam, Musixmach. Songflip, Google play music, Amazon music, Deezer, Itunes, dan lain sebagainya. Sementara untuk kegiatan lainnya yaitu membangun kerjasama dengan resto and café, bar and resto serta event organizer agar grup Green Flame bisa tampil secara off air di berbagai tempat.

\section{Kesimpulan}

Dari hasil analisis temuan penelitian dan pembahasan yang telah maka dapat ditarik simpulan yang dapat menjawab pertanyaan penelitian pada penelitian kegiatan marketing public relations yang dilakukan oleh label musik Digital Audio Tape dapat disimpulkan sebagai berikut :

1. Marketing public Relations yang dilakukan oleh label musik Digital Audio Tape dalam melakukan promosi untuk menarik perhatian konsumen agar menggunakan jasa studio rekaman, serta dikelola manajemen artisnya oleh pihak label Digital Audio Tape. Pihak label menggunakan three way strategy yaitu : pull, push, pass strategy di mana ketiga konsep tersebut satu sama lainnya saling berkaitan dan berhubungan. Menurut pernyataan dan pandangan dari ketiga narasumber di ciptakannya three way strategy pada kegiatan marketing public Relations yang dilakukan oleh label musik Digital Audio Tape bertujuan untuk menciptakan daya tarik, mendorong, serta membujuk masyarakat sebagai calon talent potensi agar lebih kenal lebih jauh tentang label sehingga mempunyai peminatan terhadap label sehingga terdorong untuk menggunakan jasa rekaman di label serta berminat untuk di manajemen keartisannya.

2. Menangani hambatan yang terjadi pada promosi yang dilakukan oleh label musik Digital Audio Tape yang terjadi pada promosi yang dilakukan oleh label musik Digital Audio Tape, executive public relation Digital Audio Tape berusaha membangun komunikasi baik dengan talent potensi agar bermitra, ataupun bekerjasama dengan label dan merilis single atau albumnya di label Digital Audio Tape serta membangun branding label bersama-sama. Selain itu, executive public relation Digital Audio Tape berusaha membangun komunikasi dengan Kompetitor dan stokeholder dengan tujuan untuk menciptakan beberapa aspek terutama adanya bantuan dari pihak kompetitor atapun 
stokeholder untuk memperkenalkan label dengan di bangunkan karater label sesuai dengan karakter label.

3. Mengapa Digital Audio Tape melakukan promosi melalui group rapper Green Flame. Pertama musik hip hop sebagai musik yang menjanjikan di era digital saat ini, di mana masyarakat sebagai khalayak sudah mulai mengenal dan menyukai musik tersebut. Sementara dalam mempromosikan dan memarketingkan grup Green Flame hal tersebut di sebabkan karena grup tersebut memunyai konsep hip-hop berbeda penuh warna karena Green Flame di bentuk dari para talent yang mempunyai genre musik yang berbeda, di satukan menjadi jenis hip hop tanpa merubah karakter dari genre musik yang di bawakan oleh setiap personal talent-nya. Hal tersebutlah yang menjadi kemudian pihak label menjawab alasan dalam mempromosikan produk jasa labelnya yaitu Green Flame. Sementara dalam proses memasarkan Green Flame itu sendiri rilisannya dimasukan di berbagai macam layanan musik streaming seperti JOOX Music, Sportify, Shazam, Musixmach. Songflip, Google play music, Amazon music, Deezer, Itunes, dan lain sebagainya. Sementara untuk kegiatan lainnya yaitu membangun kerjasama dengan resto and café, bar and resto serta event organizer agar grup Green Flame bisa tampil secara off air di berbagai tempat

\section{E. Saran}

\section{Saran Akademis}

Dalam membahas strategi marketing public relations, peneliti menyarankan sebaiknya penjelasan mengenai Three Ways Strategy untuk dijelaskan lebih mendetail sehingga dapat berguna untuk pengembangan keilmuan komunikasi pada umumnya dan public relations pada khususnya sehingga referensi tersebut dapat menjadi acuan bagi para peneliti selanjutnya yang ingin membahas mengenai strategi marketing public relations dalam sebuah perusahaan.

\section{Saran Praktis}

1. Sebaiknya pihak label D.A.T selalu menciptaka inovasi baru untuk meningkatkan daya tawar dan daya tarik dari calon talent agar bisa menggunakan jasa rekaman di label tersebut. Adapun inovasi tersebut berupa menciptakan berbagai bentuk event yang menarik dan tidak terduga sehingga masyarakat sebagai konsumen pendengar dan talent potensi berminat untuk menggunakan dan membeli produk dan jasa label tersebut.

2. Dalam menangani hambatan yang terjadi pada promosi yang dilakukan oleh label musik Digital Audio Tape, penulis menyarankan sebaiknya komunikasi tatap muka atau antar personal terus di lakukan agar label dengan mitra dari talent dan kolega lainnya terus menjaga kerjasama baik secara bisnis musik maupun kebersamaan dalam memajukan label D.A.T.

\section{Daftar Pustaka}

Alifahmi, Hifni. 2008. Marketing Public Relations. Jakarta: Lembaga Manajemnen Fakultas Ekonomni Universitas Indonesia.

Ardianto, Elvinaro, 2011, Handbook of Public Relations. Bandung: Simbiosa Reklatama Media. Cangara, Hafied. 2005. Pengantar Ilmu Komunikasi. Jakarta: PT. Raja Grafindo.

Ruslan, Rosady. 2008. Manejemen Public Relations dan Media Komunikasi. Jakarta: PT. RajaGrafindo Persada. 